\title{
Stephanie Ross and Larry Savage, eds., Retbinking the Politics of Labour in Canada (Halifax, Winnipeg: Fernwood Press, 2012).
}

This book is about the things unions do when they are not organizing, bargaining, walking picket lines, or handling grievances. It is about their political efforts to improve the conditions under which they pursue their core business of the collective sale of labour power to employers. The book comes in three parts. The first gives a theoretical explanation of the historical development of unions and their relations to the state and employers in Canada and introduces the notions of business- versus social movement unionism as a framework for actual and potential politics of labour. The second part focuses on electoral politics in English-Canada and Québec, discusses strategic voting, i.e. union endorsement of non-social democratic parties, and electoral reform. The third part, finally, looks at the collaboration of unions with various non-union groups and organizations in the field of extra-parliamentary politics. Respective chapters are devoted to women, aboriginal peoples, immigrants and the work with environmentalists and anti-poverty activists. The editors call for "more radical and militant political strategies" (16) and there is no indication that their co-authors disagree with this. Thus, the book aims at going beyond scholarly inquiry into the field of political intervention. A brief discussion will show that achieving this goal would have required going a few steps further than the authors actually did.

For a start, in her own chapter co-editor Stephanie Ross points at the limitations of the business- vs. social movement unionism dichotomy and insists that the key to any successful union strategy is their anchoring in the workplace. Considering the tendency in some progressive union circles to treat community activism as a substitute for the decline of union density and membership engagement, this is an urgently needed reminder. Unfortunately, neither her nor any other chapter of the book raises the question which organizing and mobilizing strategies might be as successful in today's world of global networks of production and distribution as industrial unionism was in the good old days of the assembly line. In this book, the politics of labour are strictly confined to the relations between unions and non-union actors even though one might say that the internal life of unions is political, too, and that the "working-class politics" (16), which the editors also propagate, would require a complementary overhaul of internal structures and of the relations between unions, parties, and civil society groups. Yet, even though the book contains recurrent references to class politics none of the authors took the time to explain what the working class looks like today and what future class politics could possibly be. Rather than exploring class and class struggle as drivers of economic and political developments and situating unions within this context, most authors in the book take neoliberal 
globalization as an independent variable to which unions have to adjust. Framing the debate about the politics of labour in this way is self-defeating because it doesn't leave any room for unions, or other workers' organizations, to be an active force of change. And it points at another missing piece in the book. If globalization, neoliberal or other, is taken as a point of reference one would at least expect some thought about the relations between the Canadian and other national labour movements, if not about the potential for a truly international movement. The silence on this matter is particularly striking because debate about these issues figured prominently on the agenda of progressive unionists and intellectuals prior to the Great Recession and the ensuing phase of stagnation and instability. This brings me to my last point. Economists consistently point at the correlation between employment levels and bargaining power and employers confirm to this point by aggressively trying to roll back labour standards that unions had negotiated prior to the crisis. Seen from this angle, unions appear as a 'sort of Sisyphus', to use Rosa Luxemburg's term. If this is the case, the equation of politics of labour with a subset of union practices renders such politics powerless since the economic crisis undermines union power in the workplace without which it doesn't have much clout outside the workplace either. Therefore, politics of labour should be redefined in a much broader way including any efforts workers, employed and unemployed, could possibly make to improve their living and working conditions. What overall assessment follows from this critique? Two thumbs up for drawing a thorough balance sheet of the politics of labour, meaning: unions, in Canada today. Plus three question marks behind the rethinking of these politics; one concerning the unmaking and remaking of the working class, one regarding the relations between workers in Canada and elsewhere, and one behind the possibilities of building strong workers' movements in times of economic crises.

Ingo Schmidt

Athabasca University

\section{Randall Wakelam, Cold War Fighters: Canadian Aircraft Procurement, 1945-54 (Vancouver: UBC Press, 2011).}

I first read Randall Wakelam's study of Aircraft procurement in Canada when it was in its original form as a Masters manuscript. Indeed, I used his work to provide historical context in my own subsequent work. As the book's roots are a Masters thesis, the study is fairly short, but this does not undermine its success as a solid description of the events of Canada's ambitious quest to design and build its own fighter aircraft into the 1950s. The additional time and effort Wakelam has put into the manuscript has yielded, as part of the Studies in Canadian Military 